\title{
COMPETENCE AND COMPENSATION AS INFLUENCE FACTORS ON AGRICULTURAL EXTENSION EMPLOYEE PERFORMANCE IN BANTEN PROVINCE
}

\author{
Nasir*
}

Human Resource Management Jakarta State University Indonesia

\section{Burhanudin Tola}

Human Resource Management Jakarta State University Indonesia

\section{Wibowo}

Human Resource Management Jakarta State University

Indonesia

\section{Hamidah}

Human Resource Management Jakarta State University Indonesia

*Corrosponding author's Email: nasir100474@gmail.com

Peer-review under responsibility of $3^{\text {rd }}$ Asia International Multidisciplanry Conference 2019 editorial board (http://www.utm.my/asia/our-team/) (C) 2019 Published by Readers Insight Publisher, lat 306 Savoy Residencia, Block 3 F11/1,44000 Islamabad. Pakistan, info@ readersinsight.net This is an open access article under the CC BY-NC-ND license (http://creativecommons.org/licenses/by-nc-nd/4.0/). 


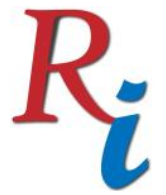

\section{Asia Proceedings of Social Sciences \\ (APSS) \\ www.readersinsight.net/APSS}

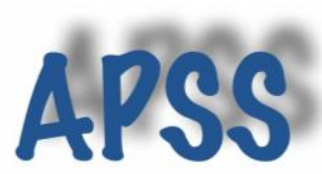

\section{Rese a r ch H i g h I igh t s}

Agricultural extension employee is an important technical employee in achieving expected farmer productivity, their performance influenced by many factor. Factors that influenced on employee performance according to references and previous research are motivation, compensation (Wibowo, 2015), competence (Anak Agung Ngurah Bagus Dhermawan, I Gde Adnyana Sudibya, 2012). This study focused on the influence of competence and compensation factor to agricultural extension employee performance in Banten Province. The result of the study showed that: (1) there is a positive direct effect of competence on performance of agricultural extension employee, (2) there is a positive direct effect of compensation on performance of agricultural extension employee and (3) there is a direct positive effect on compensation of agriculture extension employee

\section{Research Objectives}

The aims of this study is to determine and analyze the influence of competence and compensation on performance of agricultural extension employee in Banten Province

\section{Methodology}

Methodology used in this study is a survey, conducted directly to the field using a questionnaire as collection data tool. The research respondents were 94 agricultural extension employee and sample determined by cluster random sampling technique. Competence, compensation and performance were validated with product moment correlation, while reliability was measured by Cronbach Alpha, then analized using path analysis technique.

\section{Results}

1. The effect of competencies $\left(\mathrm{X}_{1}\right)$ against performance $(\mathrm{Y})$, path coefficient $\rho 11$ is 0,629 with $t_{\text {test }}=3,118$, while the value of $t_{\text {table }}=1.67(\alpha=0.05 ; \mathrm{df}=90)$. Because $t_{\text {test }}>t_{\text {table }}$, then $\mathrm{H}_{0}$ is rejected, $\mathrm{H}_{1}$ is accepted, and can be concluded that competence has a direct positive effect on performance with path coefficient of $62.9 \%$.

2. The effect of compensation $\left(\mathrm{X}_{2}\right)$ against performance $(\mathrm{Y})$, path coefficient $\rho_{\mathrm{y} 2}$ is obtained at 0,349 with $\mathrm{t}_{\text {test }}=4,731$ while the value of $\mathrm{t}_{\text {table }}=1.67(\alpha=0.05$; $\mathrm{df}=$ 90). Because $t_{\text {test }}>t_{\text {table, }}$, then, then $H_{0}$ is rejected, $H_{1}$ is accepted, and can be concluded that compensation has a positive direct effect on performance with path coefficient of $34.9 \%$.

3. The effect of competence $\left(\mathrm{X}_{1}\right)$ against compensation $\left(\mathrm{X}_{2}\right)$, path coefficient $\rho_{\mathrm{y} 1}$ is obtained at 0,458 with $\mathrm{t}_{\text {test }}=6,702$, while the value of $\mathrm{t}_{\text {table }}=1.67(\alpha=0.05$; $\mathrm{df}=$ 90). Because $t_{\text {test }}>t$ table, then $H_{0}$ is rejected, $H_{1}$ is accepted. Can be concluded that competence has a direct positive effect on employee compensation with path coefficient of $45.8 \%$

\section{Findings}

1. Competence has positive effect on performance, more positive the competence, the performance tends to increase. According to (Winanti, 2011) concluded that competence has a significant positive effect on employee performance. 


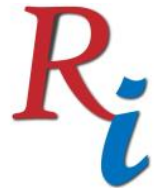

\section{Asia Proceedings of Social Sciences (APSS) \\ www.readersinsight.net/APSS}

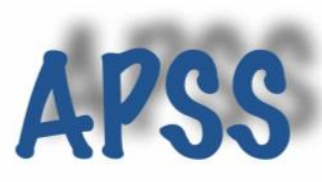

2. Compensation has a positive direct effect on performance, better compensation will initiate better of performance. According to (Kasenda, 2013) compensation has a significant effect on Employee performance with positive coefficient values.

3. Competence variables contributes to compensation, increased of competence will make a meaningful contribution to compensation. According (Firmandari, 2014) concluded that compensation in the form of salaries and allowances had an effect on Employee performance.

\section{Acknowledgement}

The author would like to thank to Head and Staff of Agricultural Extension Employee in Pandeglang Regency, Banten Province who have helped in collecting this research.

\section{References}

Anak Agung Ngurah Bagus Dhermawan, I Gde Adnyana Sudibya, I. W. M. U. (2012). Pengaruh Motivasi, Lingkungan Kerja, Kompetensi, Dan Kompensasi terhadap Kepuasan Kerja dan Kinerja Pegawai di Lingkungan Kantor Dinas Pekerjaan Umum Provinsi Bali. Jurnal Manajemen, Strategi Bisnis, dan Kewirausahaan, 6(2), 173-184.

Firmandari, N. (2014). Pengaruh Kompensasi Terhadap Kinerja Karyawan Dengan Motivasi Kerja Sebagai Variabel Moderasi (Studi Pada Bank Syariah Mandiri Kantor Cabang Yogyakarta). EKBISI, IX(1), 25-34.

Kasenda, R. (2013). Kompensasi Dan Motivasi Pengaruhnya Terhadap Kinerja Karyawan Pada PT. Bangun Wenang Beverages Company Manado. Jurnal EMBA, 1(3), 853-859. https://doi.org/2303-1174

Wibowo. (2015). Manajemen Kinerja (Edisi ke-5). Raja Grafindo Persada-Jakarta.

Winanti, M. B. (2011). Pengaruh Kompetensi Terhadap Kinerja Karyawan (Survey pada PT. Frisian Frisian Flag Indonesia Wilayah Jawa Barat). Majalah Ilmiah UNIKOM, 7(2), 249-267. 